Institute of $\mathbf{F}_{\text {ood and }} \mathbf{A}_{\text {gricultural }} \mathbf{S}_{\text {ciences }}$

\title{
Classical Biological Control of Tropical Soda Apple in the USA $^{1}$
}

J. C. Medal, J. P. Cuda, and D. Gandolfo²

\section{Introduction}

Tropical soda apple, Solanum viarum Dunal (Solanaceae), is an invasive nonnative weed of pastures and woody areas in the southeastern United States. This perennial prickly shrub, native to South America, has been spreading at an alarming rate during the last decade. Tropical soda apple was first discovered in Glades County, Florida, in 1988, and has since been reported in Alabama, Georgia, Louisiana, Texas, Mississippi, North Carolina, South Carolina, Tennessee, Pennsylvania, and Puerto Rico. In Florida, over 1 million acres are currently estimated to be infested with tropical soda apple. Cattle feed on the mature fruits of tropical soda apple and are primarily responsible for spreading the weed by passing the undigested seeds in their droppings (Figure 1).

Field surveys in South America for potential biological control agents were initiated in 1994 by researchers from the University of Florida in collaboration with the Universidade Estadual Paulista Jaboticabal campus, Sao Paulo state, Brazil, and the
USDA-ARS South American Biological Control Laboratory, Buenos Aires province, Argentina.

South American insects identified as potential biological control agents of tropical soda apple include the defoliating leaf beetle, Gratiana boliviana Spaeth (Chrysomelidae), and the flower bud weevil, Anthonomus tenebrosus Boheman (Curculionidae).

\section{The Tropical Soda Apple Leaf Beetle, Gratiana boliviana}

Host-specificity studies (choice \& no-choice feeding \& oviposition tests) conducted in Argentina and in the USA, and field surveys in South America, confirmed the high degree of specificity and damaging effect of $G$. boliviana on the foliage of tropical soda apple. A petition to release this insect from quarantine was approved by the Technical Advisory Group (TAG) for Biological Control Agents of Weeds in April 2002. Field release of this insect in Florida is anticipated in the spring of 2003.

Adults of G. boliviana (Figure 2) and larvae (Figure 3) feeding on tropical soda leaves restrict the vigor and growth rate of the plants. If established in

1. This document is ENY-824, one of a series of the Entomology and Nematology Department, Florida Cooperative Extension Service, Institute of Food and Agricultural Sciences, University of Florida. Published: September 2002. Please visit the EDIS Website at http://edis.ifas.ufl.edu. Additional information on these organisms, including many color photographs, is available at the Entomology and Nematology Department WWW site at http://entnemdept.ifas.ufl.edu/.

2. J.C. Medal, J. P. Cuda, Entomology and Nematology Department, Cooperative Extension Service, Institute of Food and Agricultural Sciences, University of Florida, Gainesville 32611 and D. Gandolfo, USDA-ARS South American Biological Control Laboratory, Hurlingham, Argentina.

The Institute of Food and Agricultural Sciences is an equal opportunity/affirmative action employer authorized to provide research, educational information and other services only to individuals and institutions that function without regard to race, color, sex, age, handicap, or national origin. For information on obtaining other extension publications, contact your county Cooperative Extension Service office. Florida Cooperative Extension Service/Institute of Food and Agricultural Sciences/University of Florida/Christine Taylor Waddill, Dean. 


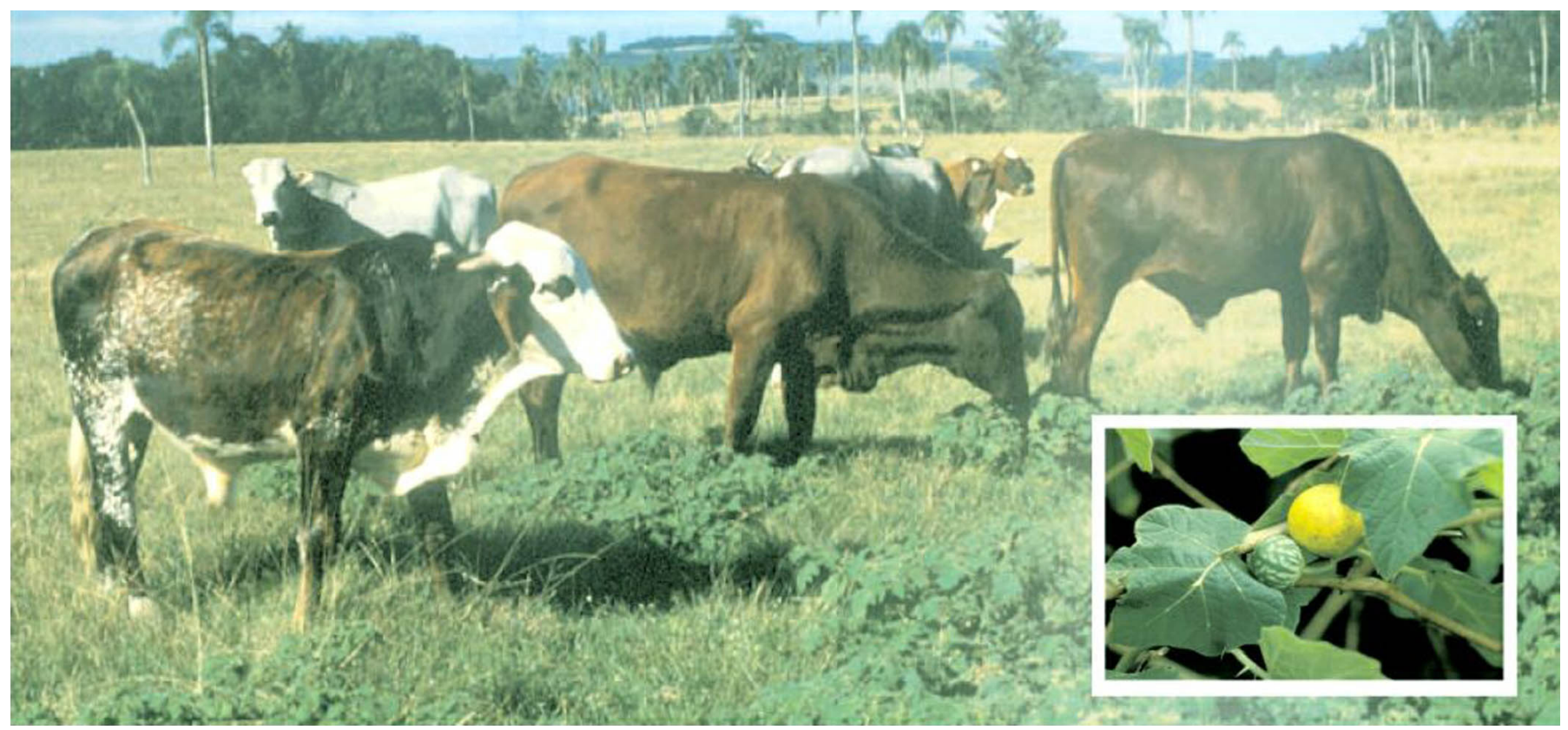

Figure 1. Cattle feeding on tropical soda apple fruits. Credits: Julio Medal, University of Florida

the USA, this leaf beetle may reduce the competitive advantage this invasive weed has over native vegetation.

The life cycle of G. boliviana begins when females deposit eggs individually on tropical soda apple leaves and petioles. Females produce an average of 300 eggs. The egg stage lasts 5-6 days at $25^{\circ} \mathrm{C}$. The larval stage is completed in $15-18$ days, and there are five instars. The pupal stage usually lasts 6-7 days. In total, 26 to 31 days are required for the insect to develop from the egg to the adult stage.

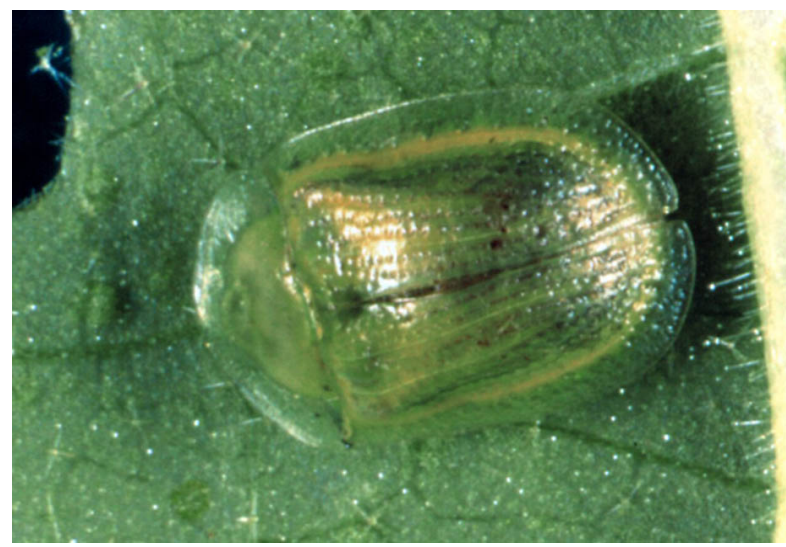

Figure 2. Gratiana boliviana adult. Credits: Jeff Lotz, Division of Plant Industry

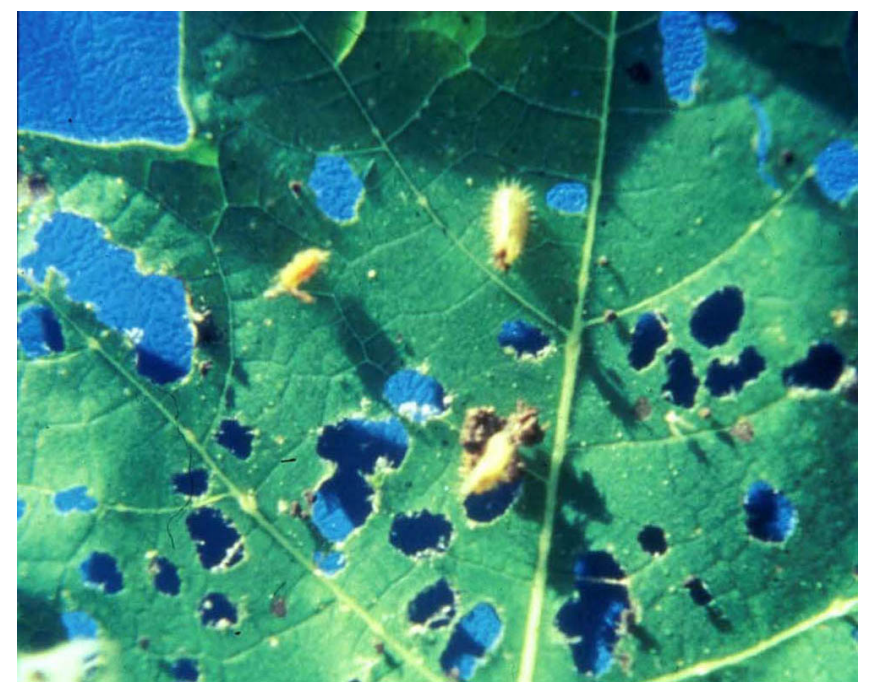

Figure 3. Larvae of Gratiana boliviana feeding on tropical soda apple. Credits: Julio Medal, University of Florida

\section{The Tropical Soda Apple Flower Bud Weevil, Anthonomus tenebrosus}

Preliminary feeding and oviposition tests with the flower bud weevil A. tenebrosus are being conducted in South America and at the Florida quarantine facility. The results obtained thus far indicate a narrow host range for this insect. The life cycle of the weevil is currently being investigated. 
Larvae of A. tenebrosus develop inside the flower buds and inhibit fruit production by causing the flowers to abort prematurely. Efforts were initiated in the summer of 2002 to develop an artificial diet for mass rearing this insect. Screening tests (laboratory and open-field) probably will be concluded during 2003. A request for field release will be submitted to the TAG committee if the additional screening tests confirm this flower bud weevil is specific to tropical soda apple.

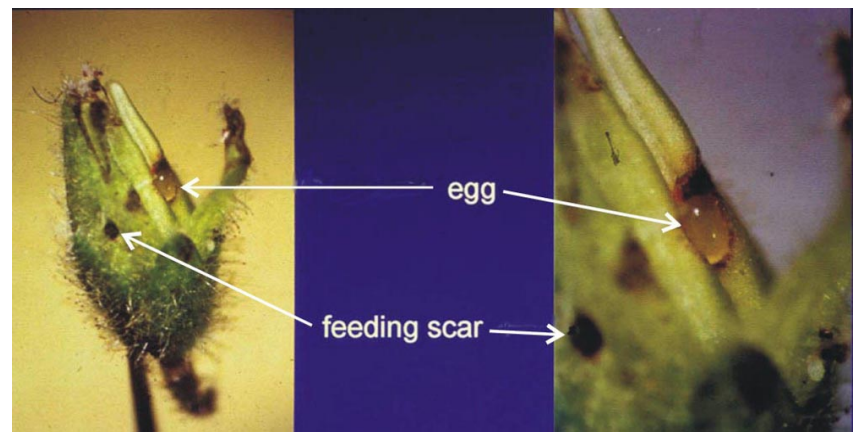

Figure 4. Egg and feeding scars of the flower-bud weevil, Anthonomus tenebrosus. Credits: Daniel Gandolfo, USDA-ARS

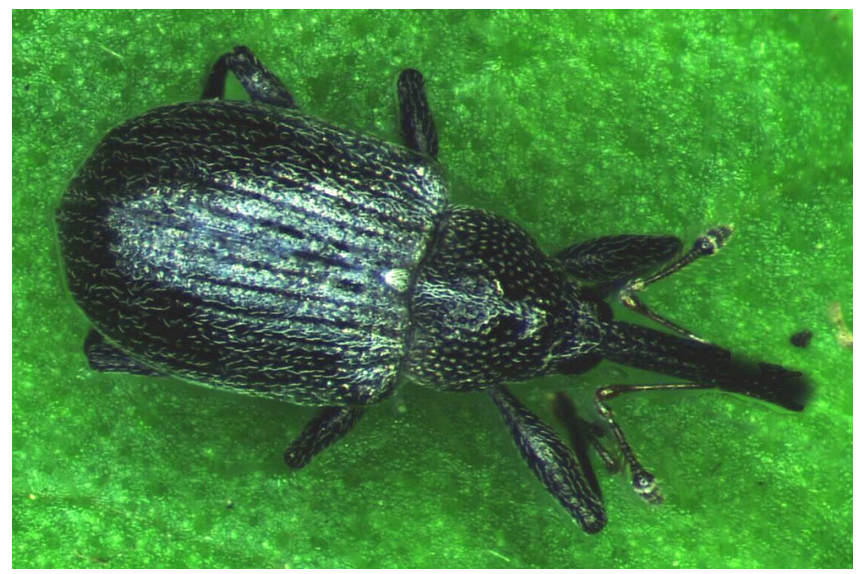

Figure 5. Adult flower-bud weevil Anthonomus tenebrosus. Credits: Stephan McJonathan

\section{Expected Impacts of Host Specific Insects on Tropical Soda Apple}

The release and establishment of the defoliating leaf beetle, G. boliviana, in the southeastern United States, followed by the introduction of other insects (e.g. the flower bud weevil A. tenebrosus currently being tested) that significantly damage the flowers, seeds, and stems may reduce the competitive ability of tropical soda apple. The establishment of a complex of host specific insects attacking different plant parts may contribute to the permanent restoration of grasslands and conservation areas currently infested with tropical soda apple.

Financial support for this project is being provided by the Florida Department of Agriculture \& Consumer Services, Division of Plant Industry (FDACS-DPI), and USDA-APHIS-PPQ. 